\title{
Effect of a compost mulch on seed germination and plant growth in a burnt forest soil from NW Spain
}

\author{
R. Paradelo ${ }^{1 *}$, R. Devesa-Rey ${ }^{1}$, J. Cancelo-González ${ }^{1}$, R. Basanta ${ }^{2}$, M.T. Pena ${ }^{3}$, F. Díaz- \\ Fierros $^{1}$ and M.T. Barral ${ }^{1}$ \\ ${ }^{1}$ Departamento de Edafoloxía e Química Agrícola, Facultade de Farmacia, Universidade de Santiago de \\ Compostela. ${ }^{2}$ UIQA. Instituto Superior de Agronomia, TULisbon (Portugal). ${ }^{3}$ Departamento de Química \\ Analítica, Nutrición e Bromatoloxía, Instituto de Investigación e Análise Alimentario, Universidade de
}

Santiago de Compostela. "Corresponding author: remigio.paradelo@usc.es

\begin{abstract}
In this work, a revegetation experiment was performed on a forest soil artificially burnt in the laboratory, and the results of the soil without treatment were compared to those of the soil capped with an organic mulch. Plant biomass, as well as the variation of $\mathrm{pH}$, electric conductivity (EC), and phytotoxicity with depth, were recorded. Only a very low plant growth was observed in the uncapped soil. The substrateamended soil had a higher production than the uncapped soil, despite showing an increased EC due to the mulch. The increase of $\mathrm{pH}$ or salinity during burning can be discarded as the cause of the different plant growth, because the values reached were not high enough to justify the negative effect observed. The determination of phytotoxicity after burning the soil at temperatures between $100^{\circ} \mathrm{C}$ and $500^{\circ} \mathrm{C}$ suggested that the problems observed for seed germination in the burnt soil might be linked to the formation of undetermined phytotoxic substances after soil heating at a temperature near $200^{\circ} \mathrm{C}$. Although polycyclic aromatic hydrocarbons followed the same trend as phytotoxicity with temperature, their concentrations in soil were too low to be the cause of the effects observed, so they can be discarded as playing an important role in phytotoxicity.
\end{abstract}

Keywords: Forest fire; Burnt soils; Heat treatment; Phytotoxicity; Mulching. 


\section{Introduction}

Forest fires have important effects on ecosystems and, in particular, on soil properties, which largely depend on the intensity and duration (severity) of the fire (Certini, 2005; Keeley, 2009). Severe fires are the cause of several negative effects on soil, including removal of organic matter, deterioration of soil structure and porosity (Díaz-Fierros et al., 1989; Jordán et al., 2011), loss of nutrients through volatilization, ash entrapment in smoke columns, leaching and erosion (Saa et al., 1994; Certini, 2005; Shakesby, 2011), and alteration of microbial and soil-dwelling invertebrate communities (Carballas et al., 1993; Vázquez et al., 1993; Certini, 2005). In order to minimize the effects caused by wildfires on soil, the ash layer needs to be stabilized, the vegetation re-established and the soil structure improved as soon as possible after the wildfire has ended (Vázquez et al., 1996).

Nevertheless, ecosystems perturbed by severe forest fires usually have a slow rate of recovery, and soil often remains bare several months after fire occurs, with the consequent risk of degradation by erosion (Neary et al., 1999). This behaviour is mainly a consequence of the loss of organic matter, the physical degradation of the soil, and the apparition of a hydrophobic layer which limits water infiltration and increases runoff and erosion (Imeson et al., 1992; DeBano, 2000; Certini, 2005). In addition to this, some authors have observed an associated apparition of toxic substances in burnt soils (Díaz-Raviña et al., 1996), which represents an additional problem for restoration, if they happen to be phytotoxic. Despite the relevance of this possibility for plant development, the phytotoxicity in burnt soils has not been widely investigated to date.

In this work, two experiments have been performed in order to investigate phytotoxicity in a forest soil burnt in the laboratory. In the first experiment, plant growth and phytotoxicity were compared in the burnt soil with and without an organic mulch. In the second experiment, the evolution of phytotoxicity was studied in the soil heated at different temperatures.

\section{Materials and Methods}

\subsection{Soil}

The soil used in the experiments was a forest soil under pine (Pinus pinaster Ait.) and acacia (Acacia melanoxylon $\mathrm{R}$. Br.), developed over granite, located on the Pedroso hill (Santiago de Compostela, Galicia, NW Spain). Six random samples of the upper $10 \mathrm{~cm}$ of the Ah horizon of the soil were taken in March 2009 and mixed in a composite sample. The soil was sieved to $<4 \mathrm{~mm}$ prior to the experiments. The soil presented an acidic $\mathrm{pH}$ (4.2) and a high organic carbon content (100 $\left.\mathrm{g} \mathrm{C} \mathrm{kg}^{-1}\right)$, usual for forest soils of the humid temperate zones of NW Spain. Similar soils in the area are classified as Haplic Umbrisols (FAO, 2006) or Humic Dystrudepts (Soil Survey Staff, 2006).

\subsection{Plant growth experiment}

An experiment was run where the plant growth on the bare burnt soil was compared to that on the same soil covered with $2 \mathrm{~cm}$ of an organic mulch. This mulch was made up of a blend of municipal solid waste (MSW) compost and composted pine bark (1:1 by volume), with a commercial polyacrylamide (Alcosorb $\left.^{\circledR}, 1 \mathrm{~g} \mathrm{~L}^{-1}\right)$. The mulch composition was selected on the basis of previous experiments where plant growth, water holding capacity and water repellence were evaluated in blends of MSW composts, composted pine bark, manure vermicompost, guar gum, bentonite and polyacrilamide (Basanta et al., 2009). Due to the relatively high cost of post-fire rehabilitation, the use of mulches composed of local materials is a 
priority, so both the MSW compost and the composted pine bark employed in the mulch formulation were provided by industries near to Santiago de Compostela. The main properties of the MSW compost were the following: $\mathrm{pH} 8.7$; total organic matter: $380 \mathrm{~g} \mathrm{~kg}^{-1}$; $\mathrm{EC}_{1: 5} 5.1 \mathrm{dS} \mathrm{m}^{-1}$. The main properties of the composted pine bark were the following: $\mathrm{pH} 5.3$; total organic matter: $914 \mathrm{~g} \mathrm{~kg}^{-1} ; \mathrm{EC}_{1: 5} 0.37 \mathrm{dS} \mathrm{m}^{-1}$.

A fraction of the soil was distributed over a $2-\mathrm{cm}$ gravel bed in four $0.25-\mathrm{m}^{2} \mathrm{PVC}$ containers, in order to reach a $10-\mathrm{cm}$ high soil layer. Another fraction of the soil was burnt in the laboratory using a set of six lamps with a total power of $3000 \mathrm{~W}$. The lamps were placed at a distance of $15 \mathrm{~cm}$ from the soil, resulting in a temperature of $300^{\circ} \mathrm{C}$ on the surface of the soil, and near $100^{\circ} \mathrm{C}$ at a depth of $2 \mathrm{~cm}$. A 5-cm high layer of the burnt soil was placed over the unburnt soil in the four containers. This experimental disposition allowed for a good reproduction of a real forest soil affected by a fire of moderate intensity, where temperatures around $300-400^{\circ} \mathrm{C}$ are reached at the surface, and soil below five centimetres is not usually affected by the fire (Carballas, 2003). Next, a 2-cm layer of the organic mulch was placed in two of the containers, whereas in the other two the soil remained bare. Two blends of seeds were employed for the revegetation experiment, each one in two of the containers, as summarized in Table 1. A mixture of Lolium perenne (ryegrass) and Lotus corniculatus (birds' foot trefoil) was employed for the treatments SRg (with bare burnt soil) and CSRg (with capped burnt soil). Also, a commercial revegetation seed blend (Semillas Zulueta, S.A.) containing autochthonous graminae and shrubs (composition shown in Table 2) was used for the treatments SAut (with bare burnt soil) and CSAut (with capped burnt soil). In all cases, the blends were used at a rate of 2 seeds per $\mathrm{cm}^{2}$. Two seed blends were employed in order to assess potential differences in plant growth as a consequence of the species composition. Seeds were randomly distributed by hand and buried a few millimetres into the surface. The four containers were then placed outside in an area protected from the rain, in May 2009, and watered daily (about one litre of water for each container) for the next sixteen weeks.

Table 1. Key to the treatments in the plant growth experiment.

\begin{tabular}{lll}
\hline Treatment & Seeds & Key \\
\hline Burnt soil & Lolium perenne, Lotus corniculatus & SRg \\
Burnt soil & Commercial revegetation blend & SAut \\
Capped burnt soil & Lolium perenne, Lotus corniculatus & CSRg \\
Capped burnt soil & Commercial revegetation blend & CSAut \\
\hline
\end{tabular}

Table 2. Composition of the commercial revegetation blend employed.

\begin{tabular}{ll}
\hline Gramineae (95 \%) & Shrubs (5 \%) \\
\hline $20 \%$ Agropyrum cristatum & $15 \%$ Cytisus scoparius \\
$35 \%$ Lolium westerwoldicum claro & $10 \%$ Ulex europeans \\
$10 \%$ Festuca arundinacea segria & $25 \%$ Crataegus monogyna \\
$7 \%$ Trifolium repens winter & $25 \%$ Erica arborea std \\
$8 \%$ Medicago lupulina virgo & $25 \%$ Erica australis std \\
$20 \%$ Festuca rubra boreal & \\
\hline
\end{tabular}


Samples of the soil profiles were taken twice: after six weeks (July 2009), and after sixteen weeks (September, 2009). The soil profiles were sampled at four points using plastic probes with a diameter of $20 \mathrm{~mm}$. Four sections corresponding to different depths (0-1 $\mathrm{cm}, 1-3 \mathrm{~cm}, 3-5 \mathrm{~cm}$, and $5-7 \mathrm{~cm}$ ) were separated from each profile, and the replicates were combined to obtain an adequate sample for analysis. It has to be noted that the depth of the profiles was lower than the initial depth, as a consequence of the settling of the soil and progressive compaction due to watering. $\mathrm{pH}$ was determined in aqueous suspensions with a 1:2.5 soilwater ratio, using a glass electrode (Crison $\mathrm{pH}-\mathrm{Meter}$ Basic 20). Aqueous extracts with a 1:5 soil-water ratio of each soil section were prepared and analyzed for electrical conductivity and phytotoxicity. EC was determined in the extracts using a conductivity meter (HANNA HI 9033). Phytotoxicity was determined by means of a germination-elongation test with garden cress (Lepidium sativum L.), performed as described in Paradelo et al. (2010). Ten seeds of cress were placed on filter paper on Petri dishes (in triplicate), and $3 \mathrm{~mL}$ of the corresponding extracts were poured to each dish. The plates were then incubated at $25^{\circ} \mathrm{C}$ for five days in the dark. The number of seeds germinated and the length of the roots were recorded, and a germination index (GI) was calculated as follows:

$$
\mathrm{GI}=100 \times \frac{\mathrm{G}}{\mathrm{G}_{\mathrm{C}}} \times \frac{\mathrm{L}}{\mathrm{L}_{\mathrm{C}}}
$$

where $\mathrm{G}$ and $\mathrm{L}$ are the germination and root growth of the samples, respectively, and $\mathrm{G}_{\mathrm{C}}$ and $\mathrm{L}_{\mathrm{C}}$ the germination and root growth of the control (distilled water), respectively.

\subsection{Soil heating experiment}

Another fraction of the soil was oven-heated for six hours at five different temperatures: 100, 200, 300, 400 and $500^{\circ} \mathrm{C}$. The following determinations were run for each treatment: total organic matter by loss on ignition at $550^{\circ} \mathrm{C}, \mathrm{pH}$ in $1: 2.5$ water suspension, electrical conductivity in 1:5 extract, water repellence, phytotoxicity in 1:5 aqueous extracts and by a direct growth test, and polycyclic aromatic hydrocarbons. The phytotoxicity of the aqueous extract was determined as explained above. For the direct growth phytotoxicity test, three Petri dishes each containing $15 \mathrm{~g}$ of soil and 15 garden cress seeds, previously soaked in water, were prepared for each soil. The Petri dishes were incubated in the dark at $25^{\circ} \mathrm{C}$ for five days, and then the germination was quantified and the root elongation measured (Moscoso et al., 2007). The germination index (GI) in this test was calculated as explained above, with the difference that here $\mathrm{G}_{\mathrm{C}}$ and $\mathrm{L}_{\mathrm{C}}$ are the germination and root growth of the non heated soil, respectively. The water repellence was evaluated by the Molarity of Ethanol Droplet (MED) test as described by King (1981) and Roy and McGill (2002). As several authors have indicated the apparition of aromatic compounds in soil during forest fires (García-Falcón et al., 2006), the presence of polycyclic aromatic hydrocarbons (PAHs) was also determined, in order to test if they may be responsible for phytotoxicity. These were extracted using a solid-phase dispersion procedure, and determined by high performance liquid chromatography (HPLC) with fluorescence detection, following the method described by Pena et al. (2007). 


\section{Results and Discussion}

\subsection{Plant growth experiment}

The utilization of the organic mulch had a very favourable effect on seed germination and plant growth in the burnt soil (Table 3). It is noteworthy that after four months, no significant plant growth was observed in the burnt soil without treatment. The plants that germinated in the uncapped soil treatments (SRg and SAut) were Acacia seedlings, whose seeds were present in the forest soil and germinated below the burnt soil. Nevertheless, the treatment with the mulch produced better results of biomass production (Table 3). It has to be noted that the autochthonous shrubs included in the commercial blends did not germinate in any treatment. Although the effects of mulching on vegetation recovery after fire are not widely known, other researchers have also observed that mulching improved the germination of seeded grasses (Robichaud et al., 2000; Carballas et al., 2009a). Mulches are commonly applied in post-fire rehabilitation to reduce the effects of rain impact and overland flow, and to keep the soil in place, as they are especially effective in increasing ground cover during the first post-fire year, when erosion is likely to be the greatest (Bautista et al., 2009). Organic matter acts by providing a suitable physical medium for seed germination, as well as preventing desiccation due to its high water holding capacity, and several studies have proved that the addition of organic wastes increases the plant cover in burnt soils, with the consequent reduction of the risk of soil erosion (Villar et al., 1998; Guerrero et al., 2000; Guerrero et al. 2001; Larchêveque et al., 2005). For example, Bautista et al. (2009) found that seeding without mulching did not increase ground cover in burnt soil, while the mulch combined with seeding produced the highest plant cover values, as a result of the increment in soil moisture content and by holding the seeds in place in the soil.
Table 3. Plant productivity in the plant growth experiment.

\begin{tabular}{lcc}
\hline Treatment & Fresh weight (g) & Dry weight (g) \\
\hline SRg & 3.2 & 0.45 \\
SAut & 1.1 & 0.19 \\
CSRg & 56.4 & 8.44 \\
CSAut & 58.7 & 7.49 \\
\hline
\end{tabular}

The severe difficulties found for seed germination in the burnt soil without mulching could be attributed to excessive salinity or extreme $\mathrm{pH}$, common features of burnt soils as reported by other authors (Giovannini, 1994; Ulery et al., 1995; Carballas et al., 2009b). However, analysis of the soil profiles taken after six weeks allowed this hypothesis to be discarded. Figure 1 shows the $\mathrm{pH}$ profiles, with their natural acid values in the deepest sections (corresponding to the unburnt soil), and higher values in the upper section of the profiles (corresponding to the layer of burnt soil and the organic mulch). Burning increased the $\mathrm{pH}$ of the soil by approximately one unit, as shown by the differences found between the surface and the deeper sections in the profiles of the non-capped soils (SRg, $\mathrm{SAut}$ ). It must be noted that this $\mathrm{pH}$ increment for the burnt soil is moderate, as a consequence of the high buffering capacity of the soil, common in Galician forest soils due to high acidity and organic matter content (Carballas et al., 2009b). The highest $\mathrm{pH}$ values were found in the surface section of the capped soils (CSRG, CSAut), as a consequence of the alkaline $\mathrm{pH}$ of the MSW compost used in the mulch. The electrical conductivity (EC) of the profiles showed a similar trend to $\mathrm{pH}$ after six weeks (Figure 1). In all cases, EC decreased with depth, but the range of variation was wider in the capped soil, which presented the highest surface EC values, as a consequence of the high salinity of MSW compost. In any case, the values were not so high as to affect plant growth -for example, values 
over $2 \mathrm{dS} \mathrm{m}^{-1}$ are usually considered as limiting for compost use (Masaguer and Benito, 2008)-, so salinity was discarded as the cause of the low plant cover observed in the burnt soil. Indeed, the capped soil showed higher salinity than the uncapped soil, and even so, plant growth was not inhibited.
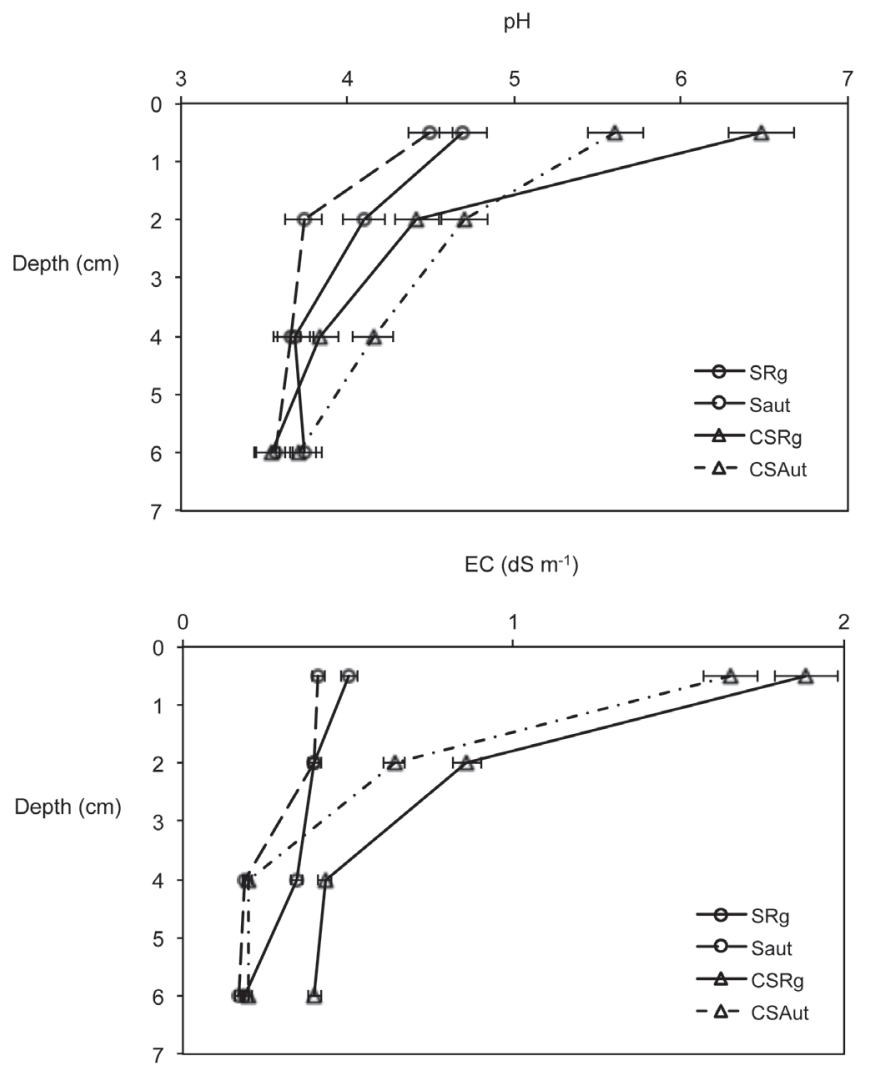

Figure 1. pH and electrical conductivity (EC) profiles in the plant growth experiment after six weeks.

Despite the intensive watering, the $\mathrm{pH}$ profiles taken after sixteen weeks (Figure 2) were overall similar to those sampled previously. The soil without mulch presented a very acidic $\mathrm{pH}$ (under 4), with little variation throughout the profile, although the values were lower than those found after six weeks. This could be attributed to the leaching of cations from the surface, which was initially less acidic. For the same reason, the deepest sections of the profile of the capped soils also presented a slightly higher $\mathrm{pH}$. The profiles of the capped soil also showed lower EC values compared to the previous profiles, especially in the upper section, which is again a consequence of leaching. The profiles of the soil without mulching were similar to those observed after six weeks of experiment. 

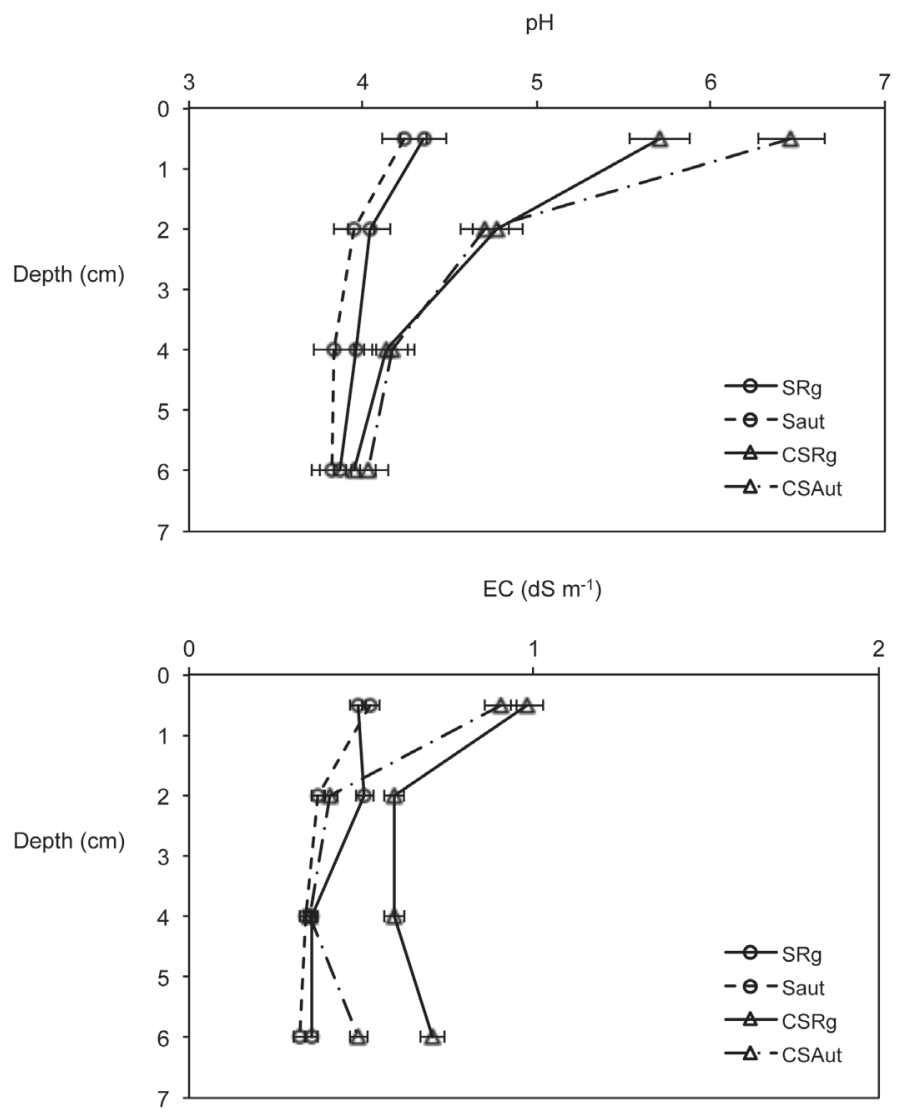

Figure 2. $\mathrm{pH}$ and electrical conductivity (EC) profiles in the plant growth experiment after sixteen weeks.

The data obtained from the two sampling times agree in that excessive $\mathrm{pH}$ or salinity cannot be the cause of the reduced plant development in the burnt uncapped soil. Therefore, other factors were also considered. One hypothesis would be the presence of phytotoxic compounds produced during the burning of the soil, which has already been observed by other researchers (Rovira and Bowen, 1966; Raison, 1979). For example, Díaz-Raviña et al. (1996) observed the toxic effects of aqueous extracts of burnt soils on bacteria, which they attributed to unidentified hydrosoluble compounds. In that case, a phytotoxic response would be detected in water extracts of the burnt soil. However, the germination test run with aqueous extracts of the soil profiles showed no phytotoxicity in any of the samples (Figure 3), which would be indicated by GI values under $80 \%$. These results suggest that phytotoxic water-soluble compounds are not the cause of the reduced plant growth observed in the burnt soil. 


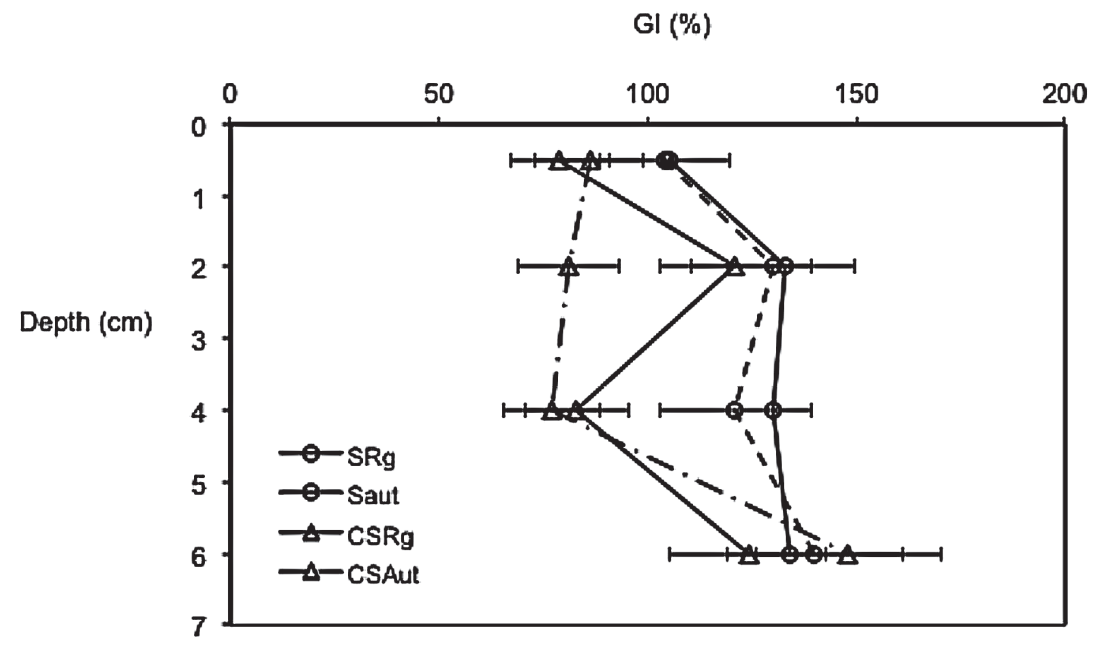

Figure 3. Germination index (GI) obtained in the water extracts of the profiles taken after sixteen weeks in the plant growth experiment.

\subsection{Soil heating experiment}

For a deeper investigation into the presence of phytotoxic substances in burnt soil, the effect of heating on some soil properties was also studied. Increasing the temperature of soil heating produced a parallel increment in soil $\mathrm{pH}$ and EC (Table 4), in agreement with what has been observed by other authors (Soto and Díaz-Fierros, 1993; Iglesias et al., 1997; Quintana et al., 2007; Úbeda et al., 2009). Both effects are commonly observed in burnt soils, and they are due to the denaturalization of organic acids and to the release of cations from burnt organic matter, respectively (Cer- tini, 2005). In the soil employed here, the $\mathrm{pH}$ and electrical conductivity did not reach extreme values which could be prejudicial for plant development, although in other soils fire has been observed to increase $\mathrm{pH}$ up to values over 10 and EC over $8 \mathrm{dS} \mathrm{m}^{-1}$, especially when temperature rises above $400^{\circ} \mathrm{C}$ (Ulery et al., 1993; Quintana et al., 2007; Úbeda et al., 2009). Soil heating also led to a progressive decline in organic matter content (Table 4), in good agreement to what was expected, as the literature has established that soil organic matter loss begins around a temperature of $200-250^{\circ} \mathrm{C}$, ending at about $460^{\circ} \mathrm{C}$ (Giovannini et al., 1988). 
Table 4. Effect of the heating temperature on soil properties (mean \pm standard deviation). T: temperature; EC: electrical conductivity; OM: organic matter; $\mathrm{GI}_{\mathrm{w}}$ : germination index in the water extract; $\mathrm{GI}_{\mathrm{s}}$ : germination index in the direct growth test.

\begin{tabular}{lcccccc}
\hline \multirow{2}{*}{ Soil properties } & \multicolumn{7}{c}{$\mathbf{T}\left({ }^{\mathbf{0}} \mathbf{C}\right)$} \\
\cline { 2 - 7 } & $\begin{array}{c}\text { unheated } \\
\text { soil }\end{array}$ & $\mathbf{1 0 0}$ & $\mathbf{2 0 0}$ & $\mathbf{3 0 0}$ & $\mathbf{4 0 0}$ & $\mathbf{5 0 0}$ \\
\hline $\mathrm{pH}$ & $4.2 \pm 0.0$ & $4.1 \pm 0.1$ & $4.7 \pm 0.1$ & $5.0 \pm 0.0$ & $5.5 \pm 0.3$ & $5.7 \pm 0.3$ \\
$\mathrm{EC}\left(\mathrm{dS} \mathrm{m}^{-1}\right)$ & $0.06 \pm 0.00$ & $0.10 \pm 0.02$ & $0.19 \pm 0.02$ & $0.15 \pm 0.00$ & $0.14 \pm 0.05$ & $0.20 \pm 0.06$ \\
$\mathrm{OM}\left(\mathrm{g} \mathrm{kg}^{-1}\right)$ & $173 \pm 3$ & $162 \pm 1$ & $61 \pm 1$ & $26 \pm 0.6$ & $2 \pm 3$ & 0 \\
Water repellence & 3.8 & 3.7 & 3.5 & 3.3 & $<0$ & $<0$ \\
$\left(\mathrm{~mol} \mathrm{~L}^{-1}\right)$ & $75 \pm 26$ & $47 \pm 6$ & $52 \pm 36$ & $58 \pm 36$ & $94 \pm 32$ & $115 \pm 24$ \\
$\mathrm{GI}_{\mathrm{w}}(\%)$ & 100 & $49 \pm 29$ & $7 \pm 8$ & $46 \pm 8$ & $35 \pm 5$ & $39 \pm 6$ \\
$\mathrm{GI}_{\mathrm{s}}(\%)$ & & & & & & \\
\hline
\end{tabular}

The development of a hydrophobic layer may have played an important role in the difficulties observed for plant development, as well as phytotoxicity, and both processes could in fact be closely related. For example, Varela et al. (2005) observed that the water repellence of burnt soils increases gradually with temperature, reaching a peak at temperatures between $220-240^{\circ} \mathrm{C}$, and disappears above $260-280^{\circ} \mathrm{C}$. Here, water repellence was already severe for the unheated soil (Table 4), as is common in Galician forest soils, which have been repeatedly burnt in the past, and it remained almost constant during heating, disappearing at a temperatures higher than $300^{\circ} \mathrm{C}$, as a consequence of the loss of organic matter. Therefore, although the development of an hydrophobic layer is common in burnt soils, in this case it cannot account for the low productivity of the burnt soil.

As for phytotoxicity, the germination test with aqueous extracts indicated that the soil was already phytotoxic before burning, and that only after the heating temperature surpassed $300^{\circ} \mathrm{C}$, was phytotoxicity reduced. Unfortunately, the high variability of the test did not allow for a better discrimination of the results at different temperatures. Nevertheless, as heating did not increase the phytotoxicity of the water extracts, the role of water-soluble compounds formed during burning was discarded, confirming the results found in the previous experiment. However, some authors have indicated that germination tests using water extracts may give an underestimation of potential toxicity when compared to tests based on direct contact with the soil (Gyuricza et al., 2010). The direct growth test (Table 4) showed that soil heating at any temperature above $100^{\circ} \mathrm{C}$ increased its phytotoxicity, and pointed to the highest presence of phytotoxic substances at about $200^{\circ} \mathrm{C}$, as the soil heated at that temperature showed a virtual absence of seed germination and development. Since the same was not observed in the germination test with extracts, this points to the presence of non-hydrosoluble phytotoxic compounds in the heated soil.

The fact that phytotoxicity appears at some point between 100 and $200^{\circ} \mathrm{C}$, and disappears at higher temperatures, could point to low weight hydrocarbons such as benzene or anthracene as the cause of phytotoxicity. It is known that these kinds of compounds are produced in soil during forest fires (García-Falcón et al., 2006; Vergnoux et al., 2011). Henner et al. (1999) 
attributed the phytotoxicity of hydrocarbon contaminated soils to compounds such as benzene, xylene, toluene and anthracene, and observed that the phytotoxicity of aromatic compounds decreases as their molecular weight increases. Therefore, phytotoxicity could be a consequence of the formation of aromatic compounds as soil organic matter is heated. However, this hypothesis should be discarded on the basis of the results of the analysis of PAHs in the soil heated at different temperatures (Table 5). Although a peak in their concentration was observed in the soil heated at $200^{\circ} \mathrm{C}$, in coincidence with the peak for phytotoxicity, the concentrations found were too low (under 1 $\mathrm{mg} \mathrm{kg}^{-1}$ in all cases) to be the cause of phytotoxicity, since phytotoxic effects of PAHs have only been reported in soil concentrations ranging from 25 to $>100$ $\mathrm{mg} \mathrm{kg}^{-1}$ (Efroymson et al., 1997). Besides, the PAHs concentrations found here are similar to values found by other authors in woodland burnt soils in Spain (García-Falcón et al., 2006), so it cannot be said that PAHs are produced during a fire episode in concentrations high enough to produce phytotoxicity.

Table 5. Effect of the heating temperature on soil PAHs concentrations (in $\mu \mathrm{g} \mathrm{kg}^{-1}$ ). T: temperature; nd: under the detection limit.

\begin{tabular}{lcccccc}
\hline \multirow{2}{*}{ PAH concentrations } & & & & $\mathbf{T}\left({ }^{\mathbf{0}} \mathbf{C}\right)$ & & \\
\cline { 2 - 7 } & unheated soil & $\mathbf{1 0 0}$ & $\mathbf{2 0 0}$ & $\mathbf{3 0 0}$ & $\mathbf{4 0 0}$ & $\mathbf{5 0 0}$ \\
\hline Naphthalene & 15 & 1.2 & 69 & 12 & 12 & 12 \\
Acenaphthene & nd & nd & nd & nd & nd & nd \\
Fluorene & 2.4 & 1.9 & 2.4 & 1.9 & 1.9 & 1.7 \\
Phenanthrene & 11 & 7.2 & 20 & 5.9 & 5.3 & 6.1 \\
Anthracene & 0.7 & nd & 0.8 & nd & nd & nd \\
Fluoranthene & 12 & 13 & 14 & nd & nd & nd \\
Pyrene & 6.9 & 4.0 & 2.8 & 1.4 & 1.4 & 1.4 \\
Benzo(a)anthracene & 2.6 & 1.8 & 0.9 & 0.4 & nd & 0.4 \\
Chrysene & 4.5 & 3.9 & 12 & nd & nd & nd \\
Benzo(e)pyrene & 8.9 & 6.9 & 1.9 & nd & nd & nd \\
Benzo(b)fluoranthene & 8.2 & 7.4 & 2.8 & nd & nd & nd \\
Benzo(k)fluoranthene & 2.6 & 2.3 & 0.3 & nd & nd & nd \\
Benzo(a)pyrene & 3.8 & 3.0 & 0.4 & nd & nd & nd \\
Dibenzo(a.h)anthracene & 0.9 & 0.7 & 0.1 & nd & nd & nd \\
Benzo(g.h.i)perylene & 6.0 & 4.6 & 1.5 & nd & nd & 0.4 \\
Indeno(1.2.3-cd)pyrene & 4.4 & 3.7 & 0.6 & nd & nd & nd \\
Total PAHs & 90 & 62 & 130 & 22 & 21 & 22 \\
\hline
\end{tabular}


Research on the phytotoxic properties of burnt soils is still scarce. On the basis of the results obtained here, which allowed us to discard salinity, $\mathrm{pH}$ or PAHs as dominant phytotoxic factors in burnt soils, we think that the difficulties observed for plant growth could be due to a combination of the negative conditions created by the hydrophobicity of the soil and the presence of undetermined phytotoxic substances. The attribution of the phytotoxicity to allelopathic substances derived from plant litter, which have been found for example in eucalyptus plantations (Molina et al., 1991), is a hypothesis of considerable interest which should be further investigated in the future.

\section{Conclusions}

In this work it was observed that plant establishment failed when seeds were placed directly in the surface of a soil burnt in the laboratory. The application of a mulch composed by a mixture of municipal solid waste compost, composted pine bark and a commercial polyacrylamide, allowed plants to germinate and establish in the burnt soil. When the difficulties found for seed germination were further assessed, it was observed that the values of $\mathrm{pH}$ and salinity reached during burning, as well as the concentrations of polycyclic aromatic hydrocarbons, were not high enough to justify the negative effect observed. Studying the phytotoxicity of the soil heated at different temperatures between 100 and $500^{\circ} \mathrm{C}$ showed the apparition of phytotoxic substances at around $200^{\circ} \mathrm{C}$, which could contribute to the lack of seed germination in the burnt soil, but whose nature remains undetermined.

\section{References}

Basanta, R., Paradelo, R., Cancelo, J., Iglesias, L., Devesa, R., Barral, M.T., Díaz-Fierros, F., 2009. Investigación de sustratos para la restauración de suelos afectados por incendios. In: J. Sánchez
Díaz, S. Asíns Velis (eds). Proceedings of the "IV Simposio nacional sobre control de la degradación de los suelos y cambio global". Valencia, Spain, pp: 95-96.

Bautista, S., Robichaud, P.R., Bladé, C., 2009. Postfire mulching. In: A. Cerdá, P. R. Robichaud (eds). Fire effects on soils and restoration strategies. Science Publishers, Jersey, pp: 353-372.

Carballas, M., Acea, M.J., Cabaneiro, C., Trasar, C., Villar, M.C., Díaz-Raviña, M., Fernández, I., Prieto, A., Saa, A., Vázquez, F.J., Zehner, R., Carballas, T., 1993. Organic matter, nitrogen, phosphorus and microbial population evolution in forest humiferous acid soils after wildfires. In: L. Trabaud, R. Prodon (eds). Fire in Mediterranean Ecosystems. Ecosystems Research Report 5. Commission of the European Communities, pp: 379-385.

Carballas, T., 2003. Los incendios forestales. In: J. J. Casares Long (ed). Reflexiones sobre el medio ambiente en Galicia. Xunta de Galicia, Santiago de Compostela, Spain, pp: 361-415.

Carballas, T., Martín A., González-Prieto, S.J., DíazRaviña, M., 2009a. Restauración de ecosistemas forestales quemados de Galicia (N.O. de España): aplicación de residuos orgánicos e impacto de los retardantes de llama. In: J. F. Gallardo Lancho (coord), J. Campo Alves, M. E. Conti (eds). Emisiones de gases con efecto invernadero en ecosistemas iberoamericanos. Sociedad Iberoamericana de Física y Química Medioambiental (SiFyQA), Salamanca, pp: 49-72.

Carballas, T., Martín, A., Díaz-Raviña, M., 2009b. Efecto de los incendios forestales sobre los suelos de Galicia. In: A. Cerdá, J. Mataix-Solera (eds). Efecto de los incendios forestales sobre los suelos en España. Cátedra, Valencia, pp: 269-301.

Certini, G., 2005. Effects of fire on properties of forest soils: a review. Ecologia 143, 1-10. 
DeBano, L.F., 2000. The role of fire and soil heating on water repellency in wildland environments: a review. J. Hydrol. 231-232, 195-206.

Díaz-Fierros, F., Benito, E., Vega, J.A., Castelao, A., Soto, B., Pérez, R., Taboada, T., 1989. Solute loss and soil erosion in burnt soil from Galicia, N.W. Spain. In: J. G. Goldammer, M. J. Jenkins (eds). Fire in Ecosystem Dynamics: Mediterranean and Northern Perspectives. S.P.B. Academic Publishing, The Hague, pp: 103-116.

Díaz-Raviña, M., Prieto, F., Bååth, E., 1996. Bacterial activity in a forest soil after soil heating and organic amendments measured by the thymidine and leucine incorporation techniques. Soil Biol. Biochem. 28, 419-426.

Efroymson, R.A., Will, M.E., Suter II, G.W., Wooten, A.C., 1997. Toxicological benchmarks for screening contaminants of potential concern for effects on terrestrial plants: 1997 Revision. Oak Ridge National Laboratory, Oak Ridge, TN, 128 p.

F.A.O., 2006. World Reference Base for Soil Resources 2006. World Soil Resources Reports, 103. Food and Agriculture Organization of the United Nations, Rome.

García-Falcón, M., Soto-González, B., SimalGándara, J., 2006. Evolution of the concentrations of polycyclic aromatic hydrocarbons in burnt woodland soils. Environ. Sci. Technol. 40, 759-763.

Giovannini, G., 1994. The effect of fire on soil quality. In: M. Sala, J. F. Rubio (eds). Soil Erosion and Degradation as a Consequence of Forest Fires. Selection of Papers from the International Conference on Soil Erosion and Degradation as Consequence of Forest Fires. Barcelona, Spain, 1991. Geoforma Ediciones, Logrono, Spain, pp: 15-27.

Giovannini, G., Luchesi, S., Giachetti, M., 1988. Effects of heating on some physical and chemical parameters related to soil aggregation and erodibility. Soil Sci. 146, 255-261.

Guerrero, C., Gómez, I., Mataix, J., Moral, R., Mataix, J., Hernández, M.T., 2000. Effect of solid waste compost on microbiological and physical properties of a burnt forest soil in field experiments. Biol. Fertil. Soil. 32, 410-414.

Guerrero, C., Gómez, I., Moral, R., Mataix-Solera, J., Mataix-Beneyto, J., Hernández, M.T., 2001. Reclamation of a burned forest soil with municipal solid waste compost: macronutrient dynamics and improved vegetation cover recovery. Bioresource Technol. 76, 221-227.

Gyuricza, V., Fodor, F., Szigeti, Z., 2010. Phytotoxic effects of heavy metal contaminated soil reveal limitations of extract-based ecotoxicological tests. Water Air Soil Pollut. 210, 113-122.

Henner, P., Schiavon, M., Druelle, V., Lichtfouse, E., 1999. Phytotoxicity of ancient gaswork soils. Effect of polycyclic aromatic hydrocarbons (PAHs) on plant germination. Org. Geochem. 30, 963969.

Iglesias, T., Cala, V., González, J., 1997. Mineralogical and chemical modifications in soils affected by a forest fire in Mediterranean area. Sci. Total Environ. 204, 89-96.

Imeson, A.C., Verstraten, J.M., van Mulligen, E.J., Sevink, J., 1992. The effects of fire and water repellence on infiltration and runoff under Mediterranean type forest. Catena 19, 345-361.

Jordán, A., Zavala, L.M., Mataix-Solera, J., Nava, A.L., Alanís, N., 2011. Effect of fire severity on water repellency and aggregate stability on Mexican volcanic soils. Catena 84, 136-147.

Keeley, J.E., 2009. Fire intensity, fire severity and burn severity: a brief review and suggested usage. Int. J. Wild. Fire 18, 116-126. 
King, P.M., 1981. Comparison of methods for measuring severity of water repellence of sandy soils and assessment of some factors that affect its measurement. Aust. J. Soil Res. 19, 275-285.

Larchêveque, M., Montès, N., Baldy, V., Dupoyet, S., 2005. Vegetation dynamics after compost amendment in a Mediterranean post-fire ecosystem. Agric. Ecosys. Environ. 110, 241-248.

Masaguer, A., Benito, M., 2008. Evaluación de la calidad del compost. In: J. Moreno, R. Moral (eds). Compostaje. Mundi-Prensa, Madrid, Spain, pp: 285-304.

Molina, A., Reigosa, M.J., Carballeira, A., 1991. Release of allelochemical agents of litter, throughfall and topsoil in plantations of Eucaliptus globulus Labill in Spain. J. Chem. Ecol. 17, 147-160.

Moscoso, F., Bouzas, S., Gil-Sotres, F., Leirós, M.C., Trasar-Cepeda, C., 2007. Suitability of the OCDE tests to estimate contamination with 2,4-dichlorophenol of soils from Galicia (NW Spain). Sci. Total Environ. 378, 58-62.

Neary, D.G., Klopatek, C.C., DeBano, L.F., Ffolliott, P.F., 1999. Fire effects on belowground sustainability: a review and synthesis. Forest Ecol. Manag. 122, 51-71.

Paradelo, R., Moldes, A.B., Prieto, B., Sandu, R.-G., Barral, M.T., 2010. Can stability and maturity be evaluated in finished composts from different sources? Compost Sci. Util. 18, 22-31.

Pena, M.T., Casais, M.C., Mejuto, M.C., Cela, R., 2007. Optimization of the matrix solid-phase dispersion sample preparation procedure for analysis of polycyclic aromatic hydrocarbons in soils: Comparison with microwave-assisted extraction. J. Chromatogr. A 1165, 32-38.

Quintana, J.R., Cala, V., Moreno, A.M., Parra, J.G., 2007. Effect of heating on mineral components of soil organic horizon from Spanish juniper (Ju- niperus thurifera L.) woodland. J. Arid Environ. 71, 45-56.

Raison, R.J., 1979. Modification of the soil environment by vegetation fires, with particular reference to nitrogen transformations: a review. Plant Soil 51, 73-108.

Robichaud, P.R., Beyers, J.L., Neary, D.G., 2000. Evaluating the effectiveness of postfire rehabilitation treatments. General Technical Report RMRSGTR-63. U.S. Department of Agriculture, Forest Service, Rocky Mountain Research Station.

Rovira, A.D., Bowen, G.D., 1966. The effects of microorganisms upon plant growth. II. Detoxication of heat-sterilized soils by fungi and bacteria. Plant Soil 25, 129-142.

Roy, J.L., McGill, W.B., 2002. Assessing soil water repellency using the molarity of ethanol droplet (MED) test. Soil Sci. 167, 83-97.

Saá, A., Trasar-Cepeda, M.C., Soto, B., Gil-Sotres, F., Díaz-Fierros, F., 1994. Forms of phosphorus in sediments eroded from burnt soils. J. Environ. Qual. 23, 739-746.

Shakesby, R.A., 2011. Post-wildfire soil erosion in the Mediterranean: Review and future research directions. Earth Sci. Rev. 105, 71-100.

Soil Survey Staff, 2006. Keys to Soil Taxonomy, $10^{\text {th }}$ ed. U.S. Department of Agriculture, Natural Resources Conservation Service, WA, USA.

Soto, B., Díaz-Fierros, F., 1993. Interactions between plant ash leachates and soil. Int. J. Wildland Fire 3, 207-216.

Úbeda, X., Pereira, P., Outeiro, L., Martin, D.A., 2009. Effects of fire temperature on the physical and chemical characteristics of the ash from two plots of cork oak (Quercus suber). Land Degrad. Develop. 20, 589-608. 
Ulery, A.L., Graham, R.C., Amrheim, C., 1993. Wood ash composition and soil $\mathrm{pH}$ following intense burning. Soil Sci. 156, 358-364.

Ulery, A.L., Graham, R.C., Chadwick, O.A., Wood, H.B., 1995. Decade scale changes of soil carbon, nitrogen and exchangeable cations under chaparral and pine. Geoderma 65, 121-134.

Varela, M.E., Benito, E., de Blas, E., 2005. Impact of wildfires on surface water repellency in soils of northwest Spain. Hydrol. Process. 19, 3649-3657.

Vázquez, F.J., Acea, M.J., Carballas, T., 1993. Soil microbial populations after wildfire. FEMS Microbiol. Ecol. 13, 93-104.
Vázquez, F.J., Petrikova, V., Villar, M.C., Carballas, T., 1996. Use of poultry manure and plant cultivation for the reclamation of burnt soils. Biol. Fertil. Soil. 22, 265-271.

Vergnoux, A., Malleret, L., Asia, L., Doumenq, P., Theraulaz, F., 2011. Impact of forest fires on PAH level and distribution in soils. Environ. Res. 111, 193-198.

Villar, M.C., González-Prieto, S.J., Carballas, T., 1998. Evaluation of three organic wastes for reclaiming burnt soils: Improvement in the recovery of vegetation cover and soil fertility in pot experiments. Biol. Fertil. Soil. 26, 122-129. 